\title{
Effects of Some Heavy Metals in Some Morpho-Physiological Parameters in Maize Seedlings
}

\author{
${ }^{1}$ Sali Aliu, ${ }^{2}$ Bekim Gashi, ${ }^{1}$ Imer Rusinovci, ${ }^{1}$ Shukri Fetahu and ${ }^{3}$ Rame Vataj \\ ${ }^{1}$ Department of Crop Science, Faculty of Agriculture and Veterinary, University of Prishtina, Prishtina, Kosova \\ ${ }^{2}$ Department of Biology, Faculty of Natural Science, University Prishtina, Prishtina, Kosova \\ ${ }^{3}$ Department of Chemistry, Faculty of Natural Science, University Prishtina, Prishtina, Kosova
}

Received 2013-02-25, Revised 2013-03-15; Accepted 2013-03-30

\begin{abstract}
Nowadays the heavy-metal pollution of the soil is causing ever greater problems, exacerbated by the fact that the heavy metals accumulated in plants may, either directly or indirectly, find their way into animals and human beings. Maize is one of the world's most important crops, ranking third after wheat and rice, so the changes induced by one of the most toxic heavy metals. The experiment design was randomly with repetition. Prepared seeds are placed on the germinator for germination which was added $10 \mathrm{~mL} \mathrm{H}_{2} \mathrm{O}$. Cultivation lasted $15-20$ days at temperature $25^{\circ} \mathrm{C}$ in vegetative room. During the experiment in growth period are prepared the concentrations of heavy metals $\left(600 \mathrm{~mL} / 1 \mathrm{Kg}\right.$ compost); for lead $\left(\mathrm{Pb}^{2+}\right): 200 \mu \mathrm{M}$ (T1), $400 \mu \mathrm{M}$ (T2) and $400 \mu \mathrm{M}$ (T3); for cadmium $\left(\mathrm{Cd}^{2+}\right): 60 \mu \mathrm{M}$ (T4), $120 \mu \mathrm{M}$ (T5) and $180 \mu \mathrm{M}$ (T6); for Mercury $\left(\mathrm{Hg}^{2+}\right): 33 \mu \mathrm{M}(\mathrm{T} 7), 66 \mu \mathrm{M}$ (T8) dhe $100 \mu \mathrm{M}$ (T9). Elements concentrations of heavy metals (HM's) solutions include $\mathrm{Pb}, \mathrm{Cd}$ and $\mathrm{Hg}$, were examined in all (except control) treatments, because their intoxication was at higher doses compare to control and a part of them of residual od HM's in the substrate was transport in different parts of plants. The plants of maize populations for leaf area was characterized on higher values $40.48 \mathrm{~cm}^{2}$ plant ${ }^{-1}$ or expressed in percentage the variation was $82.01 \%$. The exposure of maize seedlings to $\mathrm{Pb}^{2+}, \mathrm{Cd}^{2+}$ and $\mathrm{Hg}^{2+}$ resulted in a reduction of chlorophyll and carotenoids content in leaves compare to control. From our research with different treatments with various genotype and heavy metals the differences in the content of chlorophyll effects and carotenoides was different and significantly higher at level of probability of LSD $\mathrm{p}=0.01$.
\end{abstract}

Keywords: Maize, Cadmium, Lead, Mercury, Photosynthetic Pigment

\section{INTRODUCTION}

Heavy Metals (HM's) make a significant contribution to environmental pollution as a result of human activities such as mining, smelting, power transmission, intensive agriculture (Nedelkoska and Doran, 2000) or heavy metal contamination affects the biosphere in many places worldwide (Meagher, 2000). HM's can affect plant growth and production in a multiple way by inhibiting a number of physiological processes in plants. They were shown to cause disturbance in plant ion (Wallace et al., 1992; Barcelo et al., 1986) and water balance to interfere with protein metabolism through influencing nitrate and Corresponding Author: Bekim Gashi, Department of Biology, Faculty of Natural Science, Universiteti Prishtina, Prishtina, Kosova sulphate reduction (Nussbaum et al., 1988; Hernandez et al., 1997). A major environmental concern due to dispersal of urban and industrial waste generated by human activities is the contamination of soil with heavy metals. Polluted soil poses a severe problem to both health and land problem (Akhionbare et al., 2010). The discharge of heavy metals as a by product of various human activities has been accompanied by large scale soil pollution (Shivhare and Sharma, 2012). They present a risk for primary and secondary consumers and ultimately humans (Zeller and Feller, 1999). Among toxic metals, Lead $(\mathrm{Pb})$ and Cadmium $(\mathrm{Cd})$ appear to be the most dangerous to the environment 
(Malkowski et al., 2005). $\mathrm{Pb}^{2+}$ and $\mathrm{Cd}^{2+}$, are growth inhibition, ion uptake and transport disturbances, enzyme activation or inhibition photosynthesis (Fargasova, 2001; Geebelen et al., 2002). Mercury (Hg) poisoning has become a problem of current interest as a result of environmental pollution on a global scale. The availability of soil $\mathrm{Hg}$ to plants is low and there is a tendency for $\mathrm{Hg}$ accumulation in the roots. Indicating that roots serve as a barrier to $\mathrm{Hg}$ uptake (Tripathi and Tripathi, 1999). Cereals in this case maize are known to be good accumulators of contaminants (Malgorzata and Andzej, 2005). The mechanisms of heavy metal toxicity on photosynthesis is still a matter of speculations, this may be partly due to the differences in experimental design, but some evidence points to the involvement of electron transport in lights reactions (Giardi et al., 1997). The lack of cultivable and productive land has been attributed to soil contamination from high rate of heavy metals (USEPA, 1997). Land contamination/degradation is a threat to sustainable agricultural development and food security in developing countries (Adejumo et al., 2011). Many researchers have investigated the uptake and accumulation of Lead $(\mathrm{Pb})$ and Cadmium $(\mathrm{Cd})$ in different plant species. However, the mechanism of accumulation of heavy metals is still not completely understood (Malkowski et al., 2005). $\mathrm{Pb}$ and $\mathrm{Cd}$ are the most widespread no nutrient heavy metals (Mihailovic, 2010). Also, here no exception as Kosovo, through the thermal power plant in Obiliq, ferronickel Factory, or foundry in Zvecan, through released very large amount of heavy metals, which not only contaminate the land, but have negative effects on the growth and development of plants during vegetation. The aim of the experiments was to evaluate the effects of some heavy metals in maize seedlings for different physiological traits.

\section{MATERIALS AND METHODS}

\subsection{Plant Material and Growth Conditions}

The plant material which was include in our study were four different maize (Zea mays L.) genotypes; Local maize population (LMP's) originating from Kosova, while Bodrog (H-4), MV277 (H-6) and Miranda (H-12) were from Agricultural Institute in MartonvasarHungary. The seeds were disinfected with $\mathrm{HgCl}_{2} \quad 0.01 \%$ for $20 \mathrm{sec}$ and $70 \%$ ethanol for $5 \mathrm{~min}$, to avoid fungal contamination and then rinsed three times with distilled water and after were sterilized. Maize seeds were germinated on moistened filter paper. Prepared seeds are placed on the germinator for germination which was added $10 \mathrm{~mL} \mathrm{H}_{2} \mathrm{O}$ for ten days in temperature $25^{\circ} \mathrm{C}$. During these periods are prepared compost (minimum 1 $\mathrm{kg} /$ replicates) pots for cultivars and each treatment. In totally are 9 pots for heavy metals include $\mathrm{PbCl}_{2}, \mathrm{CdCl}_{2}$, $\mathrm{HgCl}_{2}$ and 1 control. The maize seedlings were transferred to compost in $1 \mathrm{~kg}$ weight of pots in controlled environment cabinets or controlled rooms with a 12 photoperiod and temperature $25 / 19^{\circ} \mathrm{C}$ day/night and $75 \%$ relative humidity. The compost consisted of $\mathrm{pH}\left(\mathrm{CaCl}_{2}\right)=5.8$; salt concentration $\left(\mathrm{g} \mathrm{L}^{-1}\right.$ $\mathrm{KCl}=0.9$; Nitrogen $\left(\mathrm{NH}_{4}+\mathrm{NO}_{3}\right) \mathrm{mg} \mathrm{L}^{-1} \mathrm{CaCl}_{2}=120$; Phosphorus $\left(\mathrm{P}_{2} \mathrm{O}_{5}\right) \mathrm{mg} \mathrm{L^{-1 }} \mathrm{CAL}=150$ and potassium $\left(\mathrm{K}_{2} \mathrm{O}\right) \mathrm{mg} \mathrm{L}^{-1} \mathrm{CAL}=200$. During the experiment in growth period are prepared the concentrations of heavy metals $\left(600 \mathrm{~mL} / 1 \mathrm{Kg}\right.$ compost); For lead $\left(\mathrm{Pb}^{2+}\right): 200 \mu \mathrm{M}$ (T1), $400 \mu \mathrm{M}$ (T2) and $400 \mu \mathrm{M}$ (T3); for cadmium $\left(\mathrm{Cd}^{2+}\right)$ : $60 \mu \mathrm{M}$ (T4), $120 \mu \mathrm{M}$ (T5) dhe $180 \mu \mathrm{M}$ (T6); for Mercury $\left(\mathrm{Hg}^{2+}\right): 33 \mu \mathrm{M}$ (T7), $66 \mu \mathrm{M}$ (T8) dhe $100 \mu \mathrm{M}$ (T9). These concentration of heavy metals corresponding with concentration of substrate in $\mathrm{mg} \mathrm{kg}^{-1}: \mathrm{T} 1-\mathrm{Pb}^{2+}, 25 \mathrm{mg}$ $\mathrm{kg}^{-1} ; \mathrm{T} 2-\mathrm{Pb}^{2+}, 50 \mathrm{mg} \mathrm{kg}{ }^{-1}$; $\mathrm{T} 3-\mathrm{Pb}^{2+}, 25 \mathrm{mg} \mathrm{kg}{ }^{-1} ; \mathrm{T} 4-\mathrm{Cd}^{2+}$, $4 \mathrm{mg} \mathrm{kg}{ }^{-1}$; $\mathrm{T} 5-\mathrm{Cd}^{2+}, 8 \mathrm{mg} \mathrm{kg}$; $\mathrm{T} 6-\mathrm{Cd}^{2+}, 12 \mathrm{mg} \mathrm{kg}$; $\mathrm{T} 7$ - $\mathrm{Hg}^{2+}, 4 \mathrm{mg} \mathrm{kg}{ }^{-1}$; $\mathrm{T} 8-\mathrm{Hg}^{2+}, 8 \mathrm{mg} \mathrm{kg}{ }^{-1}$; $\mathrm{T} 9-\mathrm{Hg}^{2+}, 12 \mathrm{mg}$ $\mathrm{kg}^{-1}$. Pigments were extracted by grinding $60-80 \mathrm{mg}$ freshly sampled leaves in $80 \%(\mathrm{v} / \mathrm{v})$ acetone/water containing $\mathrm{MgCO}_{3}(0.5 \% \mathrm{w} / \mathrm{v})$ at room temperature for $24 \mathrm{~h}$ in the dark. Photosynthetic pigments of all the samples were extracted in triplicate to minimize experimental errors. Concentration of chlorophyll and carotenoid contents were measured by using absorbance recorded at 662,644 and $440 \mathrm{~nm}$ for maximum absorption of chlorophyll 'a' (Chl a), chlorophyll 'b' $(C h l b)$ and Carotenoids, respectively. The extinction coefficients were determined by a UV-Vis spectrophotometer (SECOMAM, Anthelie Advanced 5). Pigment contents were calculated in $\mathrm{mg} \mathrm{g}^{-1}$ Fresh leaf Weight (FW) by applying the absorption coefficient equations described by Lichtenthaler (1986):

$$
\begin{aligned}
& \text { Chl a (mg } \left.\mathrm{g}^{-1} \quad \mathrm{FW}\right)=\left[\begin{array}{lll}
9.784 & \text { (OD662) }-0.99
\end{array}\right. \\
& \text { (OD644)] } \times \mathrm{V} / \mathrm{FW} \\
& \left.\begin{array}{lllll}
C h l & b & (\mathrm{mg} & \mathrm{g}^{-1} & \mathrm{FW}
\end{array}\right)=\left[\begin{array}{ll}
21.426 & \text { (OD644)-4.65 }
\end{array}\right. \\
& \text { (OD662) }] \times \mathrm{V} / \mathrm{FW} \\
& \text { Carotenoids }\left(\mathrm{mg} \mathrm{g}^{-1} \mathrm{FW}\right)=[4.695(\mathrm{OD} 440)-0.268(C h l \\
& a+C h l b)] \times \mathrm{V} / \mathrm{FW}
\end{aligned}
$$

Where:

$$
\begin{aligned}
\mathrm{FW} & =\text { Fresh leaf weight } \\
\mathrm{OD} & =\text { Optical Density } \\
\mathrm{V} & =\text { Volume of sample }
\end{aligned}
$$

After 15 days of exposure, the following parameters were determined in different part of plants include; Heavy Metal Contents (HMC), Leaf Area (LA), chlorophylls a, b and carotenoids concentrations. All analysis for determination of HM's including: $\mathrm{Pb}^{2+}, \mathrm{Cd}^{2+}$ and $\mathrm{Hg}^{2+}$ was 
done by Spectrophotometer of Atomic Absorber (SAA) Thermo Elemental M, by U.S. EPA Method 245.5 Cold Vapor Atomic Absorption Spectroscopy.

LA was determined according to the formula: $\mathrm{A}=$ $\mathrm{L} \times \mathrm{W} \times 0.75$, where $\mathrm{L}$ is the leaf length, $\mathrm{W}$ is the leaf width, 0.75 is the factor of recalculation for maize. The same formula has been used by Aliu et al. (2010).

\subsection{Statistical Analyses}

The experiment was performed in a randomized design with five (5) replicates. Differences among the $\mathrm{Pb}^{2+}, \mathrm{Cd}^{2+}, \mathrm{Hg}^{2+}$ and other morpho-physiological parameters were tested using MINITAB-14, statistical program. Mean separation within columns are done by Duncan's Multiple Range test.

\section{RESULTS}

The soil content with $\mathrm{Pb}, \mathrm{Cd}$ and $\mathrm{Hg}$ are shown in Table 1. The $\mathrm{Pb}^{2+}, \mathrm{Cd}^{2+}$ and $\mathrm{Hg}$ concentrations were significantly higher in the treatments T3. Elements concentrations of HM's solutions include $\mathrm{Pb}^{2+}, \mathrm{Cd}^{2+}$ and $\mathrm{Hg}^{2+}$, were examined in all (except control) treatments, because their intoxication was at higher doses compare to control and a part of them of residual HM's in the substrate was transport in different parts of plants. The differences for the concentration of $\mathrm{Pb}^{2+}$ in the substrate and content of plant were highly significant between genotypes. Higher content was found in the third treatment $\mathrm{T} 3$ (even in the substrate in plants) with the average values of $64.54 \mathrm{mg} \mathrm{kg}^{-1}$ (H-4) and $101.32 \mathrm{mg}$ $\mathrm{kg}^{-1}$ (LMP's). While with very low absorption values are determined for the substrate at H-6 $\left(26.31 \mathrm{mg} \mathrm{kg}^{-1}\right)$ and in plant content with lead was $\mathrm{H}-12\left(9.23 \mathrm{mg} \mathrm{kg}^{-1}\right.$. The differences for the content of $\mathrm{Pb}$ in the substrate compared to the control were very high significant at all genotypes, while compare the differences between the two extreme values between genotypes were $+39.23 \mathrm{mg}$ $\mathrm{kg}^{-1}$ or with variation on $86.37 \%$ and the content of heavy metals in plants was higher significant differences, these differences were extreme values $+92.09 \mathrm{mg} \mathrm{kg}^{-1}$ or with variation of $166.61 \%$. Result are Presented in Table 1. Also the significant differences were found between treatments for HM's include $\mathrm{Cd}^{2+}$ and $\mathrm{Hg}^{2+}$ at all genotypes that were in the research. The presence of cadmium in the soil substrate was with different concentrations. A higher value of $\mathrm{Cd}$ is determined to T3 in the genotype H-6 (34.38 $\mathrm{mg} \mathrm{kg}$ ) and compared with the control value $(0.28)$ differences were $34.1 \mathrm{mg} \mathrm{kg}^{-1}$. And in plant residues for the content of $\mathrm{Cd}^{2+}$, the higher value is found to $\mathrm{T} 3$ in the genotype $\mathrm{H}-12$ with average values of $35.31 \mathrm{mg} \mathrm{kg}^{-1}$. The higher presence of $\mathrm{Hg}$ in soil substrate was determined in T3 respectively at H-6 genotypes on average value $109.72 \mathrm{mg} \mathrm{kg}$, relatively higher concentration. Also the content of $\mathrm{Hg}$ in plant residues was evident with a presence of $83.43 \mathrm{mg} \mathrm{kg}^{-1}$. Results presented in Table 1. In our results for LA, the experimental average values $\mu$ were $22.24 \mathrm{~cm}^{2}$ plants $^{-1}$. The plants of LMP's for LA was characterized on higher values $40.48 \mathrm{~cm}^{2}$ plant $^{-1}$. Compare to experimental value $\mu$ the differences were significantly higher $+18.24 \mathrm{~cm}^{2}$ plant $^{-1}$ or expressed in percentage the variation was $82.01 \%$, presented in Fig. 1 .

The exposure of maize seedlings to $\mathrm{Pb}^{2+}, \mathrm{Cd}^{2+}$ and $\mathrm{Hg}^{2+}$ resulted in a reduction of chlorophyll and carotene content in leaves compare to control. From our research with different treatments with various genotype and heavy metals the differences in the content of chlorophyll effects and Carotenoides was different and significantly higher at level of probability of LSD $p=0.01$. In plants of LMP's the effect with a high reduction in the content of chlorophyll $a$ was found to treatment of third-content of $\mathrm{Cd}$ (0.696) and for the content of chlorophyll b, $\mathrm{a}+\mathrm{b}$ and carotenoides effect was the content of lead in the third treatment but not excluding $\mathrm{Cd}$ and $\mathrm{Hg}$.

Table 1. Contents of heavy metals ( $\mathrm{mg} \mathrm{kg}^{-1}$ soil) in soil substrates and maize seedlings

\begin{tabular}{|c|c|c|c|c|c|c|c|c|}
\hline \multirow[b]{2}{*}{ Treatment } & \multicolumn{4}{|c|}{ Soil Content with HM's } & \multicolumn{4}{|c|}{ Plants content with HM's } \\
\hline & LMP's & $\mathrm{H} 4$ & $\mathrm{H}-6$ & $\mathrm{H}-12$ & LMP's & $\mathrm{H}-4$ & H-6 & $\mathrm{H}-12$ \\
\hline Control & -4.97 & -6.55 & -5.70 & -6.09 & 0.51 & 6.67 & 5.02 & 5.73 \\
\hline $\mathrm{T} 1 / \mathrm{mg} \mathrm{Pb}$ & 6.60 & 6.60 & 1.05 & 10.15 & 13.40 & 20.27 & 10.58 & 7.94 \\
\hline $\mathrm{T} 2 / \mathrm{mg} \mathrm{Pb}$ & 11.21 & 23.16 & 21.49 & 38.24 & 15.24 & 23.61 & 23.17 & 7.66 \\
\hline $\mathrm{T} 3 / \mathrm{mg} \mathrm{Pb}$ & 49.52 & 64.54 & 26.31 & 43.85 & 101.32 & 43.64 & 35.83 & 9.23 \\
\hline Control & -0.71 & 0.07 & 0.28 & 1.12 & -0.40 & 0.05 & 0.29 & 0.89 \\
\hline $\mathrm{T} 1 / \mathrm{mg} \mathrm{Cd}$ & 4.92 & 8.22 & 4.55 & 5.85 & 10.30 & 14.39 & 7.81 & 20.84 \\
\hline $\mathrm{T} 2 / \mathrm{mg} \mathrm{Cd}$ & 10.86 & 11.22 & 6.12 & 8.60 & 15.92 & 23.33 & 10.82 & 23.53 \\
\hline $\mathrm{T} 3 / \mathrm{mg} \mathrm{Cd}$ & 12.01 & 15.44 & 34.38 & 14.52 & 19.09 & 27.13 & 27.65 & 35.31 \\
\hline Control & 1.23 & 2.69 & 2.52 & 1.99 & 2.14 & 2.85 & 2.68 & 2.05 \\
\hline $\mathrm{T} 1 / \mathrm{mg} \mathrm{Hg}$ & 5.38 & 4.37 & 36.51 & 5.79 & 9.17 & 27.10 & 22.33 & 16.04 \\
\hline $\mathrm{T} 2 / \mathrm{mg} \mathrm{Hg}$ & 9.30 & 4.98 & 37.85 & 40.10 & 9.31 & 35.59 & 26.71 & 22.56 \\
\hline $\mathrm{T} 3 / \mathrm{mg} \mathrm{Hg}$ & 11.89 & 6.41 & 109.72 & 44.28 & 9.75 & 83.43 & 32.95 & 37.24 \\
\hline
\end{tabular}


Sali Aliu et al. / American Journal of Biochemistry and Biotechnology 9 (1): 27-33, 2013

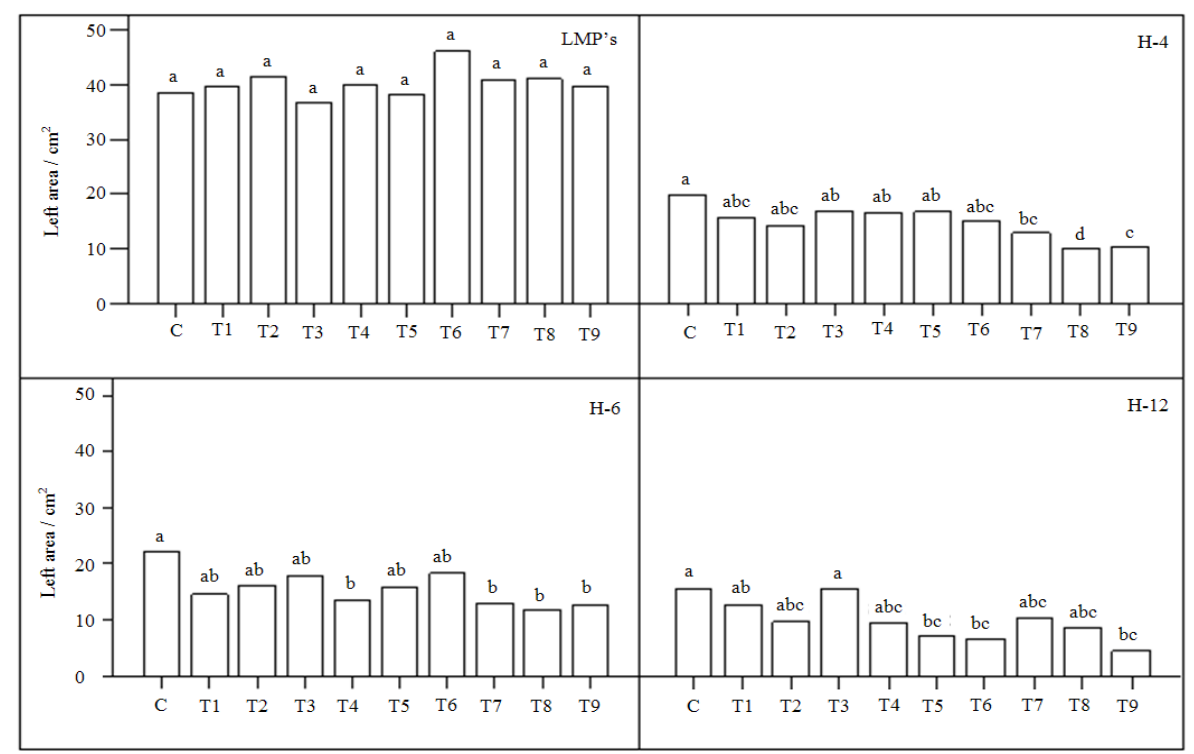

Fig. 1. The effects of different concentration of lead, cadmium and mercury on leaf area in maize seedlings

Table 2. The effects of different concentration of lead $\left(\mathrm{Pb}^{2+}\right)$, cadmium $\left(\mathrm{Cd}^{2+}\right)$ and mercury $\left(\mathrm{Hg}^{2+}\right)$ on photosynthetic pigment contents of different maize seedlings

\begin{tabular}{|c|c|c|c|c|c|c|c|c|c|c|c|c|c|c|c|c|}
\hline \multicolumn{5}{|c|}{ LMP's } & \multicolumn{4}{|l|}{$\mathrm{H} 4$} & \multicolumn{4}{|l|}{ H6 } & \multicolumn{4}{|l|}{$\mathrm{H} 12$} \\
\hline & $\mathrm{Chl}$ a & Chl b & Total Chl & Carot. & $\mathrm{Chl}$ a & Chl b & Total Chl & Carot. & $\mathrm{Chl} \mathrm{a}$ & Chl b & Total Chl & Carot. & $\mathrm{Chl} \mathrm{a}$ & Chl b & Total Chl & Carot. \\
\hline$\overline{\mathrm{C}}$ & $0.905^{\mathrm{a}}$ & $0.201^{\mathrm{b}}$ & $1.104^{\mathrm{a}}$ & $0.331^{\mathrm{a}}$ & $0.891^{\mathrm{a}}$ & $0.123^{\mathrm{a}}$ & $1.013^{\mathrm{a}}$ & $0.360^{\mathrm{a}}$ & $0.974^{\mathrm{a}}$ & $0.259^{\mathrm{a}}$ & $1.232^{\mathrm{a}}$ & $0.347^{\mathrm{a}}$ & $0.782^{\mathrm{a}}$ & $0.143^{\mathrm{a}}$ & $0.925^{\mathrm{a}}$ & $0.615^{\mathrm{a}}$ \\
\hline $\mathrm{T} 1$ & $0.529^{\mathrm{d}}$ & $0.085^{\mathrm{d}}$ & $0.614^{\mathrm{e}}$ & $0.212^{\mathrm{de}}$ & $0.865^{\mathrm{ab}}$ & $0.105^{\mathrm{abc}}$ & $0.988^{\mathrm{ab}}$ & $0.328^{\mathrm{abc}}$ & $0.634^{\mathrm{b}}$ & $0.147^{f}$ & $0.781^{\mathrm{de}}$ & $0.235^{\mathrm{d}}$ & $0.749^{\mathrm{a}}$ & $0.132^{\mathrm{a}}$ & $0.882^{\mathrm{ab}}$ & $0.269^{\mathrm{ab}}$ \\
\hline $\mathrm{T} 2$ & $0.802^{\mathrm{abc}}$ & $0.138^{\mathrm{a}}$ & $0.940^{\mathrm{f}}$ & $0.198^{\mathrm{e}}$ & $0.836^{\mathrm{abc}}$ & $0.102^{\mathrm{abcd}}$ & $0.938^{\text {abcd }}$ & $0.340^{\mathrm{ab}}$ & $0.892^{\mathrm{a}}$ & $0.203^{\mathrm{cd}}$ & $1.095^{\mathrm{abc}}$ & $0.328^{\mathrm{abc}}$ & $0.759^{\mathrm{a}}$ & $0.156^{\mathrm{a}}$ & $0.915^{\mathrm{ab}}$ & $0.279^{\mathrm{ab}}$ \\
\hline $\mathrm{T} 3$ & $0.761^{\mathrm{abc}}$ & $0.160^{\mathrm{bc}}$ & $0.921^{\mathrm{f}}$ & $0.225^{\mathrm{cde}}$ & $0.855^{\mathrm{abc}}$ & $0.098^{\text {abcd }}$ & $0.953^{\mathrm{abc}}$ & $0.345^{\mathrm{ab}}$ & $0.745^{\mathrm{ab}}$ & $0.198^{\text {cde }}$ & $1.060^{\mathrm{abc}}$ & $0.312^{\mathrm{abc}}$ & $0.853^{\mathrm{a}}$ & $0.175^{\mathrm{a}}$ & $1.027^{\mathrm{a}}$ & $0.308^{\mathrm{ab}}$ \\
\hline $\mathrm{T} 4$ & $0.870^{\mathrm{ab}}$ & $0.201^{\mathrm{b}}$ & $1.07^{\mathrm{ab}}$ & $0.325^{\mathrm{a}}$ & $0.764^{\mathrm{abc}}$ & $0.074^{\mathrm{bcd}}$ & $0.838^{\text {bed }}$ & $0.316^{\mathrm{abc}}$ & $0.822^{\mathrm{ab}}$ & $0.187^{\mathrm{de}}$ & $1.009^{\mathrm{bc}}$ & $0.305^{\mathrm{abc}}$ & $0.743^{\mathrm{a}}$ & $0.140^{\mathrm{a}}$ & $0.883^{\mathrm{ab}}$ & $0.267^{\mathrm{ab}}$ \\
\hline T5 & $0.775^{\mathrm{abc}}$ & $0.166^{\mathrm{bc}}$ & $0.940^{\text {cd }}$ & $0.278^{\mathrm{abc}}$ & $0.724^{\mathrm{c}}$ & $0.057^{\mathrm{d}}$ & $0.781^{\mathrm{d}}$ & $0.289^{\mathrm{c}}$ & $0.779^{\mathrm{ab}}$ & $0.173^{\text {ef }}$ & $0.952^{\text {cd }}$ & $0.292^{\mathrm{bc}}$ & $0.784^{\mathrm{a}}$ & $0.167^{\mathrm{a}}$ & $0.951^{\mathrm{ab}}$ & $0.291^{\mathrm{ab}}$ \\
\hline T6 & $0.696^{\mathrm{c}}$ & $0.132^{\text {cd }}$ & $0.829^{\mathrm{d}}$ & $0.258^{\text {bcde }}$ & $0.821^{\mathrm{abc}}$ & $0.116^{\mathrm{ab}}$ & $0.925^{\text {abcd }}$ & $0.342^{\mathrm{ab}}$ & $0.803^{\mathrm{ab}}$ & $0.194^{\text {cde }}$ & $0.996^{\mathrm{a}}$ & $0.296^{\mathrm{abc}}$ & $0.702^{\mathrm{a}}$ & $0.159^{\mathrm{a}}$ & $0.861^{\mathrm{ab}}$ & $0.259^{\mathrm{ab}}$ \\
\hline $\mathrm{T} 7$ & $0.795^{\mathrm{abc}}$ & $0.164^{\mathrm{bc}}$ & $0.960^{\mathrm{bc}}$ & $0.293^{\mathrm{ab}}$ & $0.844^{\mathrm{abc}}$ & $0.071^{\text {bcd }}$ & $0.915^{\text {abcd }}$ & $0.329^{\mathrm{abc}}$ & $0.617^{\mathrm{b}}$ & $0.146^{\mathrm{f}}$ & $0.763^{\mathrm{e}}$ & $0.227^{\mathrm{d}}$ & $1.651^{\mathrm{a}}$ & $0.355^{\mathrm{a}}$ & $1.029^{\mathrm{a}}$ & $0.289^{\mathrm{ab}}$ \\
\hline T8 & $0.731^{\mathrm{bc}}$ & $0.149^{\mathrm{bc}}$ & $0.880^{\text {cd }}$ & $0.273^{\mathrm{abcd}}$ & $0.798^{\mathrm{abc}}$ & $0.069^{\text {cd }}$ & $0.867^{7 \text { bcd }}$ & $0.319^{\mathrm{abc}}$ & $0.803^{\mathrm{ab}}$ & $0.237^{\mathrm{ab}}$ & $1.040^{\mathrm{bc}}$ & $0.276^{\mathrm{cd}}$ & $0.654^{\mathrm{a}}$ & $0.145^{\mathrm{a}}$ & $0.799^{\mathrm{ab}}$ & $0.241^{\mathrm{ab}}$ \\
\hline T9 & $0.812^{\mathrm{abc}}$ & $0.163^{\mathrm{bc}}$ & $0.975^{\mathrm{bc}}$ & $0.298^{\mathrm{ab}}$ & $0.735^{\mathrm{bc}}$ & $0.06^{\text {cd }}$ & $0.795^{\text {cd }}$ & $0.301^{\mathrm{bc}}$ & $0.973^{\mathrm{a}}$ & $0.219^{\mathrm{bc}}$ & $1.193^{\mathrm{ab}}$ & $0.342^{\mathrm{ab}}$ & $0.721^{\mathrm{a}}$ & $0.154^{\mathrm{a}}$ & $0.874^{\mathrm{ab}}$ & $0.264^{\mathrm{ab}}$ \\
\hline $\mathrm{X}$ & 0.7676 & 0.156 & 0.9233 & 0.2691 & 0.814 & 0.0875 & 0.9013 & 0.3269 & 0.8042 & 0.196 & 1.0121 & 0.296 & 0.839 & 0.172 & 1.011 & 0.309 \\
\hline $\mathrm{SE} \pm$ & $=0.0300$ & 0.010 & 0.040 & 0.010 & 0.010 & 0.007 & 0.0200 & 0.0060 & 0.0300 & 0.010 & 0.040 & 0.010 & 0.090 & 0.020 & 0.110 & 0.030 \\
\hline $\mathrm{CV}$ & 13.510 & 21.67 & 14.67 & 17.01 & 7.080 & 27.42 & 8.8200 & 14.090 & 15.05 & 18.40 & 15.11 & 14.09 & 34.52 & 37.88 & 34.86 & 35.31 \\
\hline
\end{tabular}

Table 3. The Correlation coefficients between traits in maize seedlings

\begin{tabular}{|c|c|c|c|c|c|c|c|c|c|c|c|c|c|c|c|c|c|}
\hline \multirow[b]{2}{*}{$\mathrm{R}$} & \multirow[b]{2}{*}{ Controll } & \multicolumn{4}{|l|}{ LMP's } & \multicolumn{4}{|l|}{$\mathrm{H}-4$} & \multicolumn{4}{|l|}{ H-6 } & \multicolumn{4}{|l|}{$\mathrm{H}-12$} \\
\hline & & Chl $-a$ & Chl- $b$ & Chl-a+b & Carot & Chl- $a$ & Chl- $b$ & Chl-a+b & Carot & Chl $-a$ & Chl- $b$ & Chl-a+b & Carot & Chl $-a$ & Chl- $b$ & Chl-a+b & Carot \\
\hline Cont & 1.000 & 0.11 & 0.166 & 0.127 & 0.441 & -0.528 & $-0.728\left(^{*}\right)$ & -0.608 & $-0.653(*)$ & 0.161 & 0.474 & 0.154 & -0.041 & -0.043 & 0.082 & -0.021 & -0.043 \\
\hline Chl- $a$ & 0.110 & 1.000 & $0.941(* *)$ & $0.997(* *)$ & $0.664(*)$ & -0.458 & -0.459 & -0.476 & -0.536 & 0.629 & 0.417 & 0.595 & $0.639\left(^{*}\right)$ & 0.126 & 0.128 & 0.126 & 0.151 \\
\hline Chl- $b$ & 0.166 & $0.941(* *)$ & 1.000 & $0.966(* *)$ & $0.804(* *)$ & -0.508 & -0.513 & -0.530 & -0.585 & 0.491 & 0.324 & 0.479 & 0.515 & 0.121 & 0.11 & 0.119 & 0.143 \\
\hline Chl- $a+b$ & 0.127 & $0.997(* *)$ & $0.966(* *)$ & 1.000 & $0.706(*)$ & -0.474 & -0.479 & -0.494 & -0.554 & 0.600 & 0.399 & 0.571 & 0.614 & 0.13 & 0.129 & 0.129 & 0.154 \\
\hline Carot & 0.441 & $0.664\left({ }^{*}\right)$ & $0.804(* *)$ & $0.706\left({ }^{*}\right)$ & 1.000 & -0.506 & -0.51 & -0.528 & -0.613 & 0.355 & 0.251 & 0.260 & 0.222 & 0.148 & 0.132 & 0.145 & 0.172 \\
\hline Chl- $a$ & -0.528 & -0.458 & -0.508 & -0.474 & -0.506 & 1.000 & $0.842(* *)$ & $0.987(* *)$ & $0.919(* *)$ & -0.406 & -0.367 & -0.351 & -0.325 & 0.191 & 0.172 & 0.189 & 0.186 \\
\hline Chl- $b$ & $-0.728\left(^{*}\right)$ & -0.459 & -0.513 & -0.479 & -0.510 & $0.842(* *)$ & 1.000 & $0.918(* *)$ & $0.894(* *)$ & -0.131 & -0.271 & -0.132 & -0.045 & -0.206 & -0.279 & -0.219 & -0.206 \\
\hline Chl $-a+b$ & -0.608 & -0.476 & -0.53 & -0.494 & -0.528 & $0.987(* *)$ & $0.918(* *)$ & 1.000 & $0.944(* *)$ & -0.339 & -0.353 & -0.299 & -0.253 & 0.078 & 0.042 & 0.072 & 0.074 \\
\hline Carot & $-0.653(*)$ & -0.536 & -0.585 & -0.554 & -0.613 & $0.919(* *)$ & $0.894(* *)$ & $0.944(* *)$ & 1.000 & -0.400 & -0.372 & -0.335 & -0.303 & 0.062 & -0.008 & 0.050 & 0.047 \\
\hline Chl- $a$ & 0.161 & 0.629 & 0.491 & 0.600 & 0.355 & -0.406 & -0.131 & -0.339 & -0.4 & 1.000 & $0.836(* *)$ & $0.953(* *)$ & $0.936(* *)$ & -0.548 & -0.522 & -0.545 & -0.519 \\
\hline Chl- $b$ & 0.474 & 0.417 & 0.324 & 0.399 & 0.251 & -0.367 & -0.271 & -0.353 & -0.372 & $0.836(* *)$ & 1.000 & $0.906(* *)$ & $0.751\left(^{*}\right)$ & -0.537 & -0.460 & -0.526 & -0.520 \\
\hline Chl- $a+b$ & 0.154 & 0.595 & 0.479 & 0.571 & 0.260 & -0.351 & -0.132 & -0.299 & -0.335 & $0.953(* *)$ & $0.906(* *)$ & 1.000 & $0.957(* *)$ & -0.559 & -0.521 & -0.555 & -0.537 \\
\hline Carot & -0.041 & 0.639 & 0.515 & 04 & 0.222 & -0.325 & -0.045 & -0.253 & -0.303 & $0.936(* *)$ & $0.751\left(^{*}\right)$ & $0.957(* *)$ & 1.000 & -0.546 & -0.529 & -0.545 & -0.525 \\
\hline Chl- $a$ & -0.043 & 0. & & & & & & 0.078 & & -0.5 & -0.5 & & -0.5 & & & $0.999(* *)$ & $0.999(* *)$ \\
\hline Chl- $b$ & & & & & & & & & & & & & -0 & $\left.0.9811^{* *}\right)$ & 1.000 & $0.987(* *)$ & $0.981(* *)$ \\
\hline Chl- $a+b$ & -0.021 & 0.126 & 0.119 & 0.129 & 0.145 & 0.189 & -0.219 & 0.072 & 0.05 & -0.545 & -0.526 & -0.555 & -0.545 & $0.999\left(^{* *}\right)$ & $0.987(* *)$ & 1.000 & $0.998(* *)$ \\
\hline Carot & -0.043 & 0.151 & 0.143 & 0.154 & 0.172 & 0.186 & -0.206 & 0.074 & 0.047 & -0.519 & -0.520 & -0.537 & -0.525 & 0.999 (**) & $0.981(* *)$ & $0.998(* *)$ & 1.000 \\
\hline
\end{tabular}

**; Correlation is significant at the 0.01 level

*; Correlation is significant at the 0.05 level 
While the other maize genotypes H-4 and H-6 the high effect in the reduction of physiological contents is determined by cadmium and mercury. Maize genotypes $\mathrm{H}-12$ is very in our study are interesting that of all the treatments for the content of chlorophyll $\mathrm{a}$ and $\mathrm{b}$ was not found any significant difference, but for the content of chlorophyll $\mathrm{a}+\mathrm{b}$ and carotenoides differences were more emphatic for probability level LSD $p=0.05$. Results are presented in Table 2. Study of correlation coefficients between evaluated characters shows different values between the traits which was included in the research. In most cases the average control value was with strong correlative values significantly higher as chlorophyll $\mathrm{a}, \mathrm{b}$ and total chlorophyll $(\mathrm{a}+\mathrm{b})$, while on carotenoid traits values the correlative values were lower and in some cases were non-significant differences as negative correlations. Results are presented in Table 3.

\section{DISCUSSION}

In the present study, exposure to HM's affected different traits of maize: leaf area and chlorophyll content include Chlorophyll 'a' (Chl a), chlorophyll 'b' $(C h l b)$ and Carotenoids. Leaf is very important photosynthetic part, which through the green pigment chlorophyll allows that light can transform kinetic energy into potential energy. The Leaf Area (LA) plays an important role in the accumulation of organic materials (Aliu et al., 2010). In our study the presence of metals includes $\mathrm{Pb}, \mathrm{Cd}$ and $\mathrm{Hg}$ at hybrid genotypes had a significant impact on reduction of LA in relation to the control and treatment concentration. This hypothesis gives us some preliminary information that local maize populations that are selected and adapted to the agro ecological conditions for centuries from our farmers, are more tolerant to environmental stress, in our case with heavy metals. Our results showed that the presence of heavy metals to plants of LMP's for LA, compared to control $\left(38.48 \mathrm{~cm}^{2}\right.$ plant $\left.^{-1}\right)$ has caused a physiological stress, which was manifested by an increase in leafy area to the three treatment at all elements of heavy metals which was include in our results. While at hybrid genotypes this phenomenon is not manifested as LMP's with increase of LA. These results shows that with the increase of LA automatically can have also increased of organic matter per unit area. From the results of Godzik (1993) for maximum $\mathrm{Pb}^{2+}$ content is found in senescing leaves and least in young leaves. From the literature we learn that in most cases the presence of heavy metals causes stress and inhibits or slows the growth processes of plants, including and maize (Stiborova et al., 1987; Rascio et al., 1993).The exposure of maize seedlings to $\mathrm{Pb}^{2+}, \mathrm{Cd}^{2+}$ and $\mathrm{Hg}^{2+}$ resulted in a reduction of chlorophyll and carotene content in leaves compare to control. The different results for total chlorophyll content were presented by Amujoyegbe et al. (2007) on values from 1.73 till 2.11. Also, by Jain et al. (2007) who investigated the effect of $\mathrm{Cd}^{+2}$ in different concentrations for content of maize Chlorophyll, it is concluded by them that the level of concentration $0.5 \mu \mathrm{M}$ the chlorophyll content was higher. The Total chlorophyll content of primary leaves decreased with increasing mercury concentration, it decreased 24.9$29.2 \%$ under treatments with $0.02,0.04$ and $0.06 \mathrm{mM}$ $\mathrm{HgCl}_{2}$ (Zengin and Munzuroglu, 2005). The results by Ghani (2010) who investigated the effect of lead in different concentrations for Chlorophyll 'a' (Chla), 'b' $\left(\begin{array}{ll}C h l & b\end{array}\right)$, his results were with higher variation and depending on the increase of the concentration, for control the Chlorophyll'a' content was 0.54 , while with $\mathrm{Pb}^{+2}$ concentration the content of Chl a was 0.386. Results presented by Burzynski (1987), show that effect of $\mathrm{Pb}^{2+}$ inhibits chlorophyll synthesis by causing impaired uptake of essential elements such as $\mathrm{Mg}$ and $\mathrm{Fe}$ by plants. Also, some results by Antosiewicz (1992) showed that the lead content tends to decrease plant organs, but this order can vary with plant species. Some plants can tolerate even concentrations of different metals without visual symptoms of toxicity (Grejtovsky et al., 2008; Seregin and Kozhevnikova, 2008). Results reported by Saderi and Zarinkamar (2012) for concentration of two HM's ( $\mathrm{Pb}$ and $\mathrm{Cd}$ ) who emphases that increased concentration to $180 \mu \mathrm{M}$, which shoot length was reduced by 79.30 and $83 \%$. It is also found that the influence of $\mathrm{Cd}^{+2}$ can affect reducing of coleoptiles, the roots of which associated with clorosis (Nocito et al., 2006). Also, some results were reported by Malecka et al. (2012) for different treatments of lead concentration resulted on higher significance with increasing of level lead concentration. Contents of HM's in plant material not always exerted direct proportionality with content of HM's in soil (Tomas et al., 2012). Metal hyper accumulating species have been identified in at least 45 plant families and individual species can accumulate different metals (Mohammad et al., 2012).

\section{CONCLUSION}

The results of our investigation substantiate the following conclusions: The effect of different of concentration of heavy metals in local maize populations for leaf area has not shown any significant differences 
effects because these genotypes seems more are adapted to environmental stress in this case to $\mathrm{Pb}, \mathrm{Cd}$ and $\mathrm{Hg}$. But, for other traits the differences were significantly higher. While in other maize genotype hybrids the effects with heavy metals was with significant differences for level of probability LSD $p=0.01$. The chlorophyll content in the treatment of control was the highest and significantly, while the lowest of chlorophyll content value at local maize populations in most cases is found in the third treatment with cadmium, while hybrids was not significant differences in mercury concentrations. This hypothesis gives us some preliminary information that local maize populations that are selected and adapted to the agro ecological conditions for centuries from our farmers, are more tolerant to environmental stress, in our case with heavy metals.

\section{REFERENCES}

Adejumo, S.A., A.O. Togun, J.A. Adediran and M.B. Ogundira, 2011. In-Situ Remediation of heavy metal contaminated soil using mexican sunflower (Tithonia diversifolia) and cassava waste composts. World J. Agric Sci., 7: 224-233.

Akhionbare, S., T. Ebe, W. Akhionbare and N. Chukwuocha, 2010. Heavy metal uptake by corn (Zea mays L.) grown on contaminated soil. Res. J. Agric. Biolog. Sci., 6: 993-997.

Aliu, S., S. Fetahu and L. Rozman, 2010. Variation of physiological traits and yield components of some maize hybrid (Zea mays L.) in agroecological conditions of Kosovo. Acta Agric. Slovenica, 95: $35-41$.

Amujoyegbe, B., B. Opabode and A. Olayinka, 2007. Effect of organic and inorganic fertilizer on yield and chlorophyll content of maize and sorghum. Afr. J. Biotechnol., 6: 1869-1873.

Antosiewicz, D.M., 1992. Adaptation of plants to an environment polluted with heavy metals. Acta Soc. Botanicorum Poloniae, 61: 281-299.

Barcelo, J., C. Cabot and C. Poshenrieder, 1986. Cadmium-Induced decrease of water stress resistance in bush bean plants (Phaseolus vulgaris L. cv. Contender) II. Effects of $\mathrm{Cd}$ on endogenous abscisic acid levels. J. Plant Physiol., 125: 27-34. DOI: 10.1016/S0176-1617(86)80240-1

Burzynski, M., 1987. Influence of lead and cadmium on the absorption and distribution of potassium, calcium, magnesium and iron in cucumber seedlings. Acta Physiol. Plantarum, 9: 229-238.
Fargasova, A., 2001. Phytotoxic Effects of Cd, Zn, Pb, $\mathrm{Cu}$ and $\mathrm{Fe}$ on Sinapis alba L. seedlings and their accumulation in roots and shoots. Biol. Plantantarum, 44: 471-473. DOI: 10.1023/A:1012456507827

Geebelen, W., J. Vangronsveld, D.C. Adriano, R. Carleer and H. Clijsters, 2002. amendment-induced immobilization of lead in a lead-spiked soil: evidence from phytotoxicity studies. Water Air Soil Pollut., 140: 261-277. DOI: 10.1023/A:1020147901365

Ghani, A., 2010. Effect of Lead Toxicity on Growth, Chlorophyll and Lead $(\mathrm{Pb}+)$ Contents of Two Varieties of Maize (Zea mays L.). Pak. J. Nutr., 9: 887-891.

Giardi, M., J. Masojidek and D. Godde, 1997. Effects of abiotic stresses on the turnover of the D1 reaction centre II protein. Plant Physiol., 101: 635-642. DOI: 10.1111/j.1399-3054.1997.tb01048.x

Godzik, B., 1993. Heavy metals content in plants from zinc dumps and reference areas. Polish Bot. Stud., 5: 113-132.

Grejtovsky, A., K. Markusova and L. Novakova, 2008. Lead uptake by Matricaria chamomilla L. Plant Soil Environ., 54: 47-54.

Hernandez, L.E., A. Garate and R. Carpena-Ruiz, 1997. Effects of cadmium on the uptake, distribution and assimilation of nitrate in Pisum sativum. Plant Soil, 189: 97-100. DOI: 10.1023/A:1004252816355

Jain, M., M. Pal, P. Gupta and R. Gadre, 2007. Effect of cadmium on chlorophyll biosynthesis and enzymes of nitrogen assimilation in greening maize leaf segments: Role of 2-oxoglutarate. Indian J. Exp. Biol., 45: 385-389.

Lichtenthaler, H., 1986. Laser-induced chlorophyll fluorescence of living plants. Proceedings of the Remote Sensing Symposium, (RSS' 86), ESA Publication Division, Nordwijk, Zurich, pp: 1571-1579.

Malecka A., A. Mensinger, A. Hanc, B. Danuta and B. Tomaszewska, 2012. Antioxidative defense system in Pisum sativum roots exposed to heavy metals. Pol. J. Environ. Stud., 6: 1721-1730.

Malgorzata, H. and N. Andzej, 2005. Monitoring of bioremediation of soil polluted with diesel fuel applying bioassays. Elect. J. Polish Agric. Univ., 8: 1-2.

Malkowski, E., R. Kurtyka and A. Kita, 2005. Accumulation of $\mathrm{Pb}$ and $\mathrm{Cd}$ and its effect on $\mathrm{Ca}$ distribution in maize seedlings (Zea mays L.). Polish J. Environ. Stud., 14: 203-207.

Meagher, R., 2000. Phytoremediation of toxic elemental and organic pollutants. Curr. Opinion Plant Biol., 3: 153-162. DOI: 10.1016/S1369-5266(99)00054-0 
Mihailovic, N., 2010. Growth and ion uptake in maize plants exposed to $\mathrm{Pb}, \mathrm{Cd}$ and $\mathrm{Ni}$ depend on $\mathrm{NO}_{3} / \mathrm{NH}_{4}$ ratio. Botanica Serbica, 34: 15-20.

Mohammad, R., R. Farhadi and M. Salehi, 2012. Effects of heavy metals on the medicinal plant. Int. J. Agronom. Plant Prod., 3: 154-158.

Nedelkoska, T. and M. Doran, 2000. Characteristics of heavy metal uptake by plant species with potential for phytoremediation and phytomining. Minerals Eng., 13: 549-561. DOI: 10.1016/S08926875(00)00035-2

Nocito, F., C. Lancilli, B. Crema, P. Fourcroy and J. Davidian et al., 2006. Heavy metal stress and sulfate uptake in maize roots. Plant Physiol., 141: 11381148. PMID: 16698905

Nussbaum, S., D. Schmutz and C. Brunold, 1988. Regulation of assimilatory sulfate reduction by cadmium in Zea mays L. Plant Physiol., 88: 14071410. PMID: 16666474

Rascio, N., F. Dallavecchia, M. Ferretti, L. Merlo and R. Ghisi, 1993. Some effects of cadmium on maize plants. Arch. Environ. Contaminat. Toxicol., 25: 244-249. DOI: $10.1007 / \mathrm{BF} 00212136$

Saderi, S. and F. Zarinkamar, 2012. The effect of different $\mathrm{Pb}$ and $\mathrm{Cd}$ concentrations on seed germination and seedling growth of Matricaria chamomilla. Adv. Environ. Biol., 6: 1940-1943.

Seregin, V. and A. Kozhevnikova, 2008. Roles of root and shoot tissues in transport and accumulation of cadmium, lead, nickel and straoncium. Fiziologiya Rastenii., $\quad$ 55: 3-26. DOI: 10.1134/S1021443708010019
Shivhare, L. and S. Sharma, 2012. Effect of Toxic heavy metal contaminated soil on an ornamental plant georgina wild. Toxicology, 2: 2-7. DOI: 10.4172/2161-0525.1000156

Stiborova, M., M. Ditrichova and A. Brezinova, 1987. Effect of heavy metal ions on growth and biochemical characteristics of photosynthesis of barley and maize seedlings. Biol. Plantarum, 29: 453-467. DOI: 10.1007/BF02882221

Tomas, J., J. Arvay and T. Toth, 2012. Heavy metals in productive parts of agricultural plants. J. Microb. Biotech. Food Sci., 1: 819-827.

Tripathi, A. and S. Tripathi, 1999. Changes in some physiological and biochemical characters in Alizia as bio-indicator of heavy metal toxicity. J. Environ. Biol., 20: 93-98.

USEPA, 1997. Innovative uses of compost bioremediation and pollution prevention.

Wallace, A., G.A. Wallace and J.W. Cha, 1992. Some modifications in trace metal toxicities and deficiencies in plants resulting from interactions with other elements and chelating agents--the special case of iron. J. Plant Nutr., 15: 1589-1598. DOI: 10.1080/01904169209364424

Zeller, S. and U. Feller, 1999. Long-distance transport of cobalt and nickel in maturing wheat. Eur. J. Agronomy, 10: 91-98. DOI: 10.1016/S11610301(98)00060-4

Zengin, F.K. and O. Munzuroglu, 2005. Effects of some heavy metals on content of chlorophyll, proline and some antioxidant chemicals in bean. Acta Biol. Cracoviensia Series Botanica, 47: 157-164. 